\title{
Annual coastal migration of juvenile Chinook salmon: static stock-specific patterns in a highly dynamic ocean
}

\author{
S. Tucker ${ }^{1, *}$, M. Trudel ${ }^{1,2}$, D. W. Welch ${ }^{1,3}$, J. R. Candy ${ }^{1}$, J. F. T. Morris ${ }^{1}$, M. E. Thiess ${ }^{1}$, \\ C. Wallace ${ }^{1}$, T. D. Beacham ${ }^{1}$ \\ ${ }^{1}$ Pacific Biological Station, Fisheries and Oceans Canada, 3190 Hammond Bay Rd, Nanaimo, British Columbia V9T 6N7, Canada \\ ${ }^{2}$ Department of Biology, University of Victoria, Victoria, British Columbia V8W 3N5, Canada \\ ${ }^{3}$ Present address: Kintama Research Services Ltd, 10-1850 Northfield Road, Nanaimo, British Columbia V9S 3B3, Canada
}

\begin{abstract}
While recent studies have evaluated the stock-specific coastal migration of juvenile Chinook salmon, it remains unclear if these seasonal patterns are consistent between years, particularly when ocean conditions change dramatically. Here we contrast the abundance, distribution and seasonal stock compositions of juvenile Chinook salmon between years in 3 oceanographic regions of the Pacific from southern British Columbia to southeast Alaska. Between 1998 and 2008, we surveyed salmon in various months from June through March, in different regions along the shelf. Variable conditions in the North Pacific Ocean, as well as large overall shifts in ocean regimes were extensively documented over this decade. We employed genetic stock identification to identify mixed-stock compositions; fish $(\mathrm{n}=6274)$ were allocated to one of 15 regional and 40 subregional stocks. Catch-per-unit-effort and distribution of salmon, as denoted by centre of mass, varied significantly between seasons, regions and years. In a similar manner, fish body size and dryweight varied significantly between years, seasons and regions. Despite these inter-annual differences in catch, distribution, fish growth performance and large variations in ocean conditions encountered by salmon over the time period of the study, we observed no response in terms of shifts in stock-specific distributions. Regional stock composition was similar between years, suggesting migration patterns for all stocks remain consistent despite fluctuations in the marine environment: local stocks remain resident in respective coastal areas during their first year at sea, except for Columbia River salmon, which move quickly into waters north of Vancouver Island in summer.
\end{abstract}

KEY WORDS: Juvenile Chinook salmon - Ocean migration - DNA stock identification . Variable ocean conditions

\section{INTRODUCTION}

The ocean environment and the prey field encountered by migrating salmon is far from static; it is complex, dynamic and in flux over multiple spatial and temporal scales (Mackas et al. 2004, 2007). Therefore the fate of salmon may depend on where and how long they reside in particular areas of the Pacific. The first few weeks to months following ocean entry are thought to be a critical time for survival, as fish must grow fast and large and accumulate sufficient energy reserves to escape both predation-based and starvation-based mortality as these are size-dependent (Willette et al. 2001, Hurst 2007, Trudel et al. 2007, MacFarlane 2010, Duffy \& Beauchamp 2011). It is now widely accepted that salmon growth rates are 
coupled to ocean conditions (Pearcy 1992, Mueter et al. 2002, Quinn et al. 2005). However, direct mechanisms linking ocean conditions, growth and survival are elusive and likely complex (Trudel et al. 2007). This is because trends in growth and marine survival among different stocks, even for geographically adjacent stocks, are not always consistent and are often asynchronous, suggesting there are potential differences in migration or ocean residency patterns (Hare et al. 1999, Mueter et al. 2002, Wells et al. 2008). Clearly, an important component is establishing where juvenile salmon live during their first few months in the ocean. Then we can explore not only the physical and biological variables that might affect salmon growth and survival but also whether salmon respond to changes in ocean conditions by altering their movement patterns.

Chinook salmon Oncorhynchus tshawytscha are widely distributed along the west coast of North America, ranging from central California to northern Alaska (Healey 1991). Chinook salmon go to sea either within a few months of hatching (sub-yearling smolts), or following a full year in fresh water (yearling smolts). Yearling type smolts predominate in the North (north of $56^{\circ} \mathrm{N}$ ), whereas sub-yearling smolts are almost exclusively distributed in the South (Healey 1991). The main exceptions are the Fraser and the Columbia River systems, as well as populations in northern Puget Sound where both types are found (Healey 1991, Teel et al. 2000, Waples et al. 2004).

Recent studies have focused both on defining marine habitat use for juvenile Chinook salmon (Bi et al. 2007, 2008, 2011a, Peterson et al. 2010) and the relationship between variable ocean conditions and abundance, growth or condition (Wells et al. 2008, MacFarlane 2010). The presence and abundance of Chinook salmon is negatively correlated with water temperature and depth, and positively correlated to various production indices such as chlorophyll (chl) a concentration and zooplankton (copepod) biomass (Brodeur et al. 2000, 2004, Fisher et al. 2007, Bi et al. 2007, 2011a, Peterson et al. 2010). These correlations between juvenile salmon abundance and environmental variables are generally weak and shift seasonally (Brodeur et al. 2004). Not all of these studies examined inter-annual differences in distribution explicitly: some were regionally restricted, and all have dealt with aggregate samples of salmon; generally only one smolttype is considered and these fish are likely a mixture of different stocks (Trudel et al. 2009, Tucker et al. 2011). Given that Chinook salmon are associated with particular environmental conditions, though not specific ones (i.e. always found within a range, which changes seasonally) it seems plausible that salmon would adjust their migration patterns based on conditions encountered once at sea. Indeed, Chinook salmon abundance and distribution along the coasts of Washington and Oregon is patchy and highly variable between cold and warm ocean years (Bi et al. 2008, Peterson et al. 2010). However without geographically widespread, concurrent sampling across the coastal shelf, coupled with knowledge of the origin of these fish, it remains unclear if variation in abundance trends for juveniles is a function of dispersal or survival.

While much research has been directed at studying the ecology and habitats occupied by juvenile salmon in the sea (reviewed by Brodeur et al. 2000, Pearcy 1992), our understanding of the stock-specific distribution and movement patterns of juvenile salmon in the ocean has only increased recently (Morris et al. 2007, Murphy et al. 2009, Trudel et al. 2009, Tucker et al. 2009, 2011, Rechisky et al. 2009, Welch et al. 2009, 2011, J. Fisher unpubl.). Seasonal migration patterns have been reconstructed through the analysis of both coded-wire tag (CWT) recoveries and the application of DNA stock identification techniques. These studies have underlined the importance of considering relevant spatial scales for assessing the effects of ocean conditions on Pacific salmon as migration varies with species, stock and life history (Trudel et al. 2009, Tucker et al. 2011, J. Fisher unpubl.). For Chinook salmon, stocks are found to remain in coastal waters near their river of origin during their 1st yr at sea irrespective of smolt type, northward migration is not initiated until the 2nd yr at sea (Trudel et al. 2009, Murphy et al. 2009, Tucker et al. 2011). The exceptions are yearling smolts from southern stocks (Fraser River, Puget Sound, coastal Washington and Oregon, Columbia River), which move quickly into waters north of Vancouver Island, including southeast Alaska; sub-yearling smolts from these stocks remain in waters of the California Current System and Puget Sound (Trudel et al. 2009, Duffy \& Beauchamp 2011, Tucker et al. 2011, J. Fisher unpubl.). What remains unclear is if these seasonal patterns are consistent between years, particularly when ocean conditions change dramatically.

Patterns of movement are considered a key factor in the survival of most organisms (e.g. Turchin 1998, Fritz et al. 2003) as many animals must move to feed. Therefore, we might expect migration patterns to deviate with local or regional conditions and prey 
availability. However, the observation of differential growth and survival between northern and southern populations of salmon (Wells et al. 2008) suggests that the ability of juvenile Chinook salmon to change their migratory behaviour in response to changing climate and ocean conditions might be limited; either they are simply unable to move out of regions with 'poor' conditions, or they are genetically constrained to simply do the same thing every year. However, there is evidence for both plasticity and inflexibility in salmon migration behaviour. For example, Beamish et al. (2002) reported dramatic changes in the behaviour of coho salmon Oncorhynchus kisutch in the Strait of Georgia coupled to abrupt climate changes, with virtually all (formerly resident) coho salmon moving out of the Strait under particular climate regimes. On the other hand, consistent stock-specific differences where tagged salmon are caught in the ocean have been observed. Both maturing coho and Chinook salmon display stock-specific marine distributions, which for the most part, are distinct from other stocks and consistent between years despite large fluctuations in ocean conditions (Weitkamp \& Neely 2002, Weitkamp 2010). However, these fish were intercepted in coastal fisheries on their return to freshwater to spawn; hence, it is not entirely certain they resided in different parts of the ocean. Differences in stable isotope values in maturing sockeye salmon suggest that there may be some spatial segregation in marine distribution between stocks as well as among sockeye populations within the Fraser River system itself (Welch \& Parsons 1993, Satterfield \& Finney 2002).

Here we contrast the abundance, distribution and seasonal stock compositions of juvenile Chinook salmon between years in 3 coastal shelf regions of the Pacific from southern British Columbia to southeast Alaska. The objective was to test for consistency in stock-specific migration patterns over a decade (1998 to 2008) that saw large fluctuations in ocean conditions (e.g. DFO 2009). Secondarily, we also evaluate whether there were in fact differences in body size (inferred growth rates) and energy densities within each season and region to evaluate potential annual differences in juvenile Chinook salmon growth performance. We employ genetic stock identification techniques to identify mixed-stock compositions in coast-wide samples. Recently, we validated genetic population assignments by showing that $96 \%$ of known-origin coded wire tagged Chinook salmon were accurately allocated to their region of origin (Tucker et al. 2011).

\section{Oceanographic setting}

Across their range, North American Chinook salmon encounter a number of distinctive ocean regions in the North Pacific. These have diverse physical and chemical oceanographic attributes as well as different biological communities (Batten et al. 2006, Batten \& Freeland 2007, Hickey \& Banas 2008). The eastward flowing Sub-Arctic Current bifurcates as it approaches the North American coast into the equator-ward flowing California Current System (CCS) and the pole-ward flowing Alaskan Coastal Current (ACC; Wells et al. 2008). These currents are driven by the relative strength of the Aleutian low pressure cell and North Pacific high pressure cell (Strub \& James 2002). The North American Pacific coast can consequently be divided into 3 general oceanographic regions: an upwelling zone south of Vancouver Island within the CCS, a downwelling zone north of Vancouver Island within the ACC, and a transition zone between the two (Wells et al. 2008). In the ACC, phytoplankton productivity is generally limited by light rather than by nutrients (Ware \& McFarlane 1989, Gargett 1997) while the CCS is primarily nutrient limited. Although total zooplankton biomass and productivity are strongly dominated by calanoid copepods in both systems, the mix of species varies (Mackas et al. 2004). Copepods are generally larger and richer in lipids in the ACC (Båmstedt 1986, Zamon \& Welch 2005) while temperature, phytoplankton and zooplankton biomass are higher in the CCS (Ware \& Thomson 2005). Oceanographic differences, as well as differences in phytoplankton and zooplankton communities are paralleled by general differences in fish community composition and abundances (Orsi et al. 2007). In terms of proportions of total catch, the CCS is dominated by clupeids such as Pacific sardines Sardinops sagax, northern anchovies Engraulis mordax, and Pacific herring Clupea pallasi, while the ACC is dominated by juvenile salmonids with a distinct breakpoint in species assemblages off Vancouver Island (Orsi et al. 2007); frequencies of occurrence of salmonids in catches are however almost equally as high in both regions. This study encompassed the northern portion of the CCS off the west coast of Vancouver Island, and the southern portion of the ACC off southeast Alaska as well as the transition zone in between the 2 current systems.

Despite the recognizable oceanographic regions, these areas are not static and demonstrate both strong seasonality as well as variability in response to multiple factors including coastal winds, freshwater runoff, solar heating, light conditions, atmospheric 
pressure, and offshore oceanic conditions (Wells et al. 2008). The seasonal cycles in turn, are modified and the variability is closely coupled with large scale events and conditions throughout the tropical and sub-arctic North Pacific Ocean, including frequent El Niño and La Niña events (particularly over the past decade). Large-scale variation in climate drives large-scale changes in ocean temperatures (Mantua et al. 1997) with attendant ecosystem effects. Some of the largest 'regime' shifts in the North Pacific of the recent past include rapid warming in the mid 1970s, cooling in the mid-late 1980s, warming from the early 1990s through 1998, rapid cooling in 1999 with continued negative temperature anomalies until 2002, and renewed warming from 2003 until 2007 (DFO 2009). In 2008, waters off the Pacific coast of British Columbia and the Southern US coast abruptly changed to the coldest observed in $50 \mathrm{yr}$, with the cooling extended far into the Pacific Ocean and corresponding large-scale changes in the plankton community (DFO 2009). The strength of the 2 main northeast Pacific current systems varies among years depending on the intensity of the Aleutian Low pressure system (Hollowed \& Wooster 1992) and are negatively correlated both intra- and inter-annually (Ware \& McFarlane 1989). Changes in horizontal transport and water temperatures due to regime shifts generally result in north-south shifts in the zooplankton community composition and the relative abundance of large and lipid-rich northern copepods (Mackas et al. 2004, Zamon \& Welch 2005, Peterson 2009, Bi et al. 2011b) as well as shifts in fish community composition (Orsi et al. 2007). This affects lipid dynamics at the base of the food web. Prey quality, in terms of the lipid quantity of food, is thought to be an important determinant in growth rates of salmon (Trudel et al. 2007, MacFarlane 2010). Recent investigations of alongshore transport suggests strong linkages among climate conditions (state of the Pacific Decadal Oscillation), direction of transport, zooplankton biomass and marine survival of juvenile coho salmon in the CCS (Bi et al. 2011b). Competition for food is expected to be more intense in the presence of high numbers of clupeids given that juvenile salmon feed on similar prey (Beamish et al. 2001, Trudel et al. 2007, Orsi et al. 2007). It follows that productivity and survival of salmon originating from different regions would be negatively correlated (Hare et al. 1999, Mueter et al. 2002). However, Chinook salmon growth rates from across these regions are not correlated (Wells et al. 2006), probably because the migratory behavior of Chinook salmon often places fish from one region into another (Healey 1991, Trudel et al. 2009, Tucker et al. 2011, J. Fisher unpubl.).

\section{MATERIALS AND METHODS}

\section{Sample collection}

Our surveys involve both repeated cross-shelf transects and opportunistic sampling from southern British Columbia to southeast Alaska between 1998 and 2008 (Fig. 1, Table 1). The sampling surveys were conducted in various months from June through March, thus allowing reconstruction of sea-
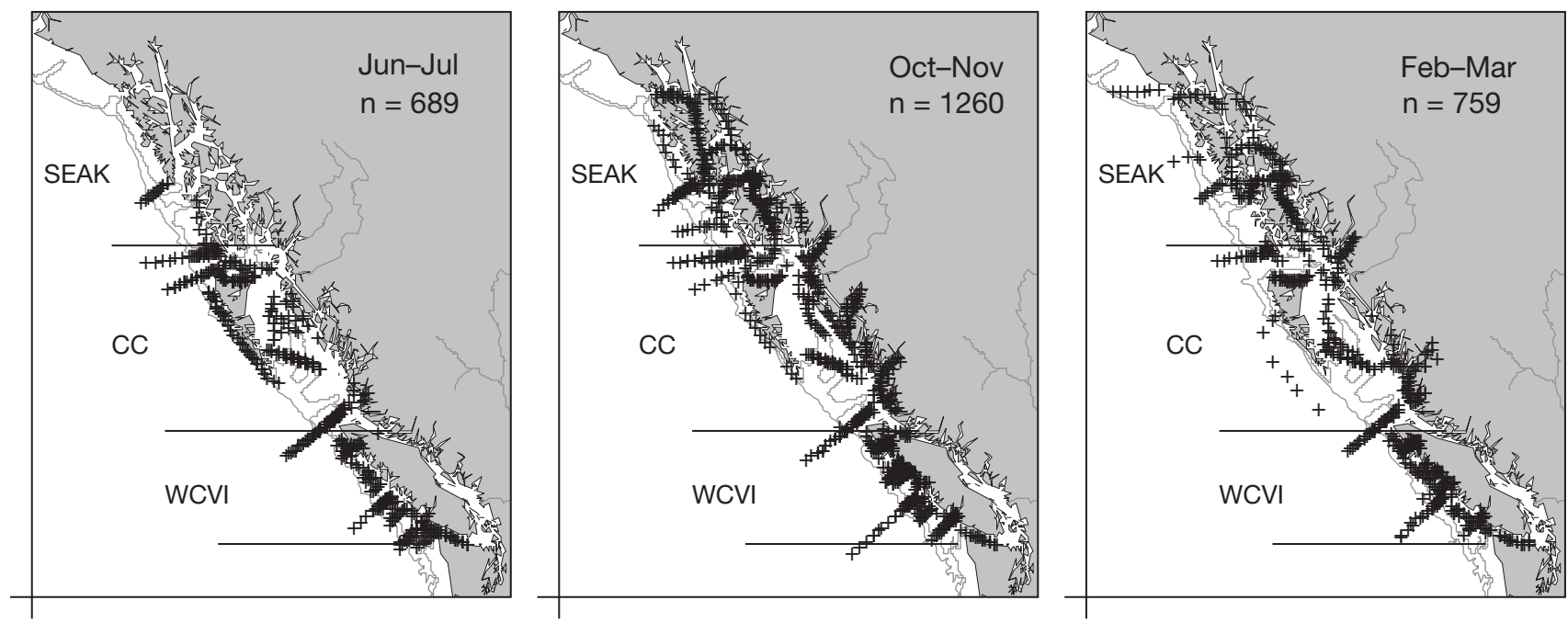

Fig. 1. Sampling locations in summer, fall, and spring. Crosses: individual fishing stations; sample sizes (n) report total number of sets. Solid lines at margin of continental shelf: $200 \mathrm{~m}$ and $1000 \mathrm{~m}$ depth contours. WCVI: west coast of Vancouver Island; CC: central British Columbia; SEAK: southeast Alaska 
Table 1. Number of tows in each season, region and year. WCVI: west coast of Vancouver Island, CC: British Columbia, SEAK: southeast Alaska

\begin{tabular}{|lcccccccccccc|}
\hline \multirow{2}{*}{ Season } & Region & 1998 & 1999 & 2000 & 2001 & 2002 & 2003 & 2004 & 2005 & 2006 & 2007 & 2008 \\
\hline Summer & WCVI & 11 & 17 & 18 & 47 & 22 & 21 & 21 & 18 & 23 & 54 & 46 \\
& CC & 48 & 26 & 9 & 28 & 47 & - & 17 & 14 & 29 & 36 & 58 \\
\multirow{5}{*}{ Fall } & SEAK & 13 & - & 8 & 20 & - & - & 7 & 7 & 8 & 16 & - \\
& WCVI & 33 & 20 & 28 & 29 & 49 & 27 & 39 & 45 & 47 & 65 & 36 \\
& CC & 16 & 13 & 44 & 59 & 20 & 36 & 28 & 53 & 23 & 70 & 47 \\
\multirow{5}{*}{ Winter } & SEAK & 9 & 22 & 55 & 59 & 53 & 32 & 52 & 32 & 45 & 21 & 53 \\
& WCVI & - & - & - & 25 & 37 & 38 & 28 & 40 & 58 & 41 & 56 \\
& CC & - & - & - & 26 & 21 & 20 & 12 & 51 & 39 & 31 & 25 \\
& SEAK & - & - & - & 30 & 28 & 17 & 23 & 33 & 35 & 45 & - \\
\hline
\end{tabular}

sonal changes in stock composition for different regions along the shelf (Tucker et al. 2011). A hexagonal mesh mid-water rope trawl $(\sim 90 \mathrm{~m}$ long $\times 30 \mathrm{~m}$ wide $\times 18 \mathrm{~m}$ deep, cod-end mesh $0.6 \mathrm{~cm}$, Cantrawl Pacific) was towed at the surface (0 to $20 \mathrm{~m}$ ) for 15 to 30 min at 5 knots using primarily the CCGS 'W.E. Ricker', or a chartered fishing vessel when it was unavailable (i.e. 'Ocean Selector' June 2002; 'Frosti' June and October 2005; 'Viking Storm' October 2007, March and June 2008). Sampling was conducted between 06:00 and 20:00 h (Pacific Time). A maximum of 30 Chinook salmon were randomly selected from each net tow, and fork length and mass were determined onboard the research vessel $(\mathrm{n}=$ $12690)$. In the lab, a sub-sample $(n=5886)$ of fish was dried at $60^{\circ} \mathrm{C}$ to constant weight to determine water content as water content or dry wt is highly correlated to energy density (Trudel et al. 2005). A tissue sample was taken from the operculum using a hole punch and preserved in 95\% ethanol for genetic stock identification $(\mathrm{n}=6274)$. By convention, all salmon are defined to be $1 \mathrm{yr}$ older on January 1. However for simplicity of discussion, we defined age categories with respect to time relative to ocean entry in spring. We refer to salmon collected between June to the following March that are in their first year of ocean life (ocean-age 0: x.0) as 'juveniles'. Oceanage separation was based on size (fork length) at capture (e.g. Orsi \& Jaenicke 1996, Fisher et al. 2007, Peterson et al. 2010, Tucker et al. 2011). We applied the following seasonal size limits to select only juvenile Chinook salmon for genetic analysis: June-July: $285 \mathrm{~mm}$, October-November: $350 \mathrm{~mm}$, FebruaryMarch $400 \mathrm{~mm}$. Fish were subsequently pooled into temporal and regional groupings with a minimum number of 5 salmon for mixed-stock analysis (see below; Table 2). To evaluate spatial changes in stock composition for juvenile salmon, we divided sampling locations into 3 catch regions (Fig. 1): west coast of Vancouver Island (WCVI), central coast of British Columbia (CC) including the west coast of the Queen Charlotte Islands (QCI), and southeast Alaska (SEAK). Samples were also pooled by season: JuneJuly, October-November and February-March. We used catch-per-unit-effort (CPUE) as a measure of relative abundance. CPUE for juvenile salmon for each fishing event was calculated separately as per Fisher et al. (2007) for regions and seasons. Briefly, CPUE was defined as the number of Chinook salmon caught per tow length of 1.5 nautical miles $(2.8 \mathrm{~km})$ where: CPUE $=[(\#$ Chinook salmon $) /$ tow duration (h)/tow speed $\left(\mathrm{n}\right.$ miles $\left.\left.\mathrm{h}^{-1}\right)\right] \times 1.5 \mathrm{n}$ miles.

Table 2. Oncorhynchus tshawytscha. Number of juvenile Chinook salmon used in mixed stock analyses. See Table 1 for definitions

\begin{tabular}{|lcccccccccccc|}
\hline \multirow{2}{*}{ Season } & Region & 1998 & 1999 & 2000 & 2001 & 2002 & 2003 & 2004 & 2005 & 2006 & 2007 & 2008 \\
\hline \multirow{2}{*}{ Summer } & WCVI & 24 & 111 & 53 & 28 & 30 & 33 & 111 & 7 & 80 & 74 & 184 \\
& CC & 60 & 38 & - & 11 & 5 & - & 14 & - & 15 & 93 & 26 \\
\multirow{5}{*}{ Fall } & SEAK & - & - & - & 7 & - & - & 5 & - & 9 & 9 & - \\
& WCVI & 38 & 115 & 17 & 142 & 132 & 90 & 103 & 236 & 657 & 108 & 339 \\
& CC & - & - & 27 & 79 & 8 & 26 & 49 & 98 & 31 & 102 & 96 \\
\multirow{5}{*}{ Winter } & SEAK & - & 5 & 103 & 106 & 103 & 33 & 90 & 149 & 140 & 72 & 151 \\
& WCVI & - & - & - & 123 & 154 & 91 & 127 & 233 & 158 & 200 & 151 \\
& CC & - & - & - & 15 & - & - & - & 17 & 10 & - & 5 \\
& SEAK & - & - & - & 105 & 65 & - & 96 & 113 & 60 & 79 & - \\
\hline
\end{tabular}


In order to reduce the influence of large catches from individual tows, we $\log _{10}$ transformed the CPUE estimate for each haul (Fisher et al. 2007). CPUEs were subsequently pooled for each region and season in each year.

\section{DNA extraction and laboratory analyses}

DNA was extracted from samples as described by Withler et al. (2000). Briefly, Chinook salmon ( $\mathrm{n}=$ 6274 juvenile) were surveyed for 12 microsatellite loci. Further details on the loci surveyed as well as the laboratory equipment used are outlined by Beacham et al. (2006a,b). A minimum of 7 loci was scored for each fish that was retained in these analyses.

\section{DNA stock allocation}

Analysis of mixed-stock samples of juvenile Chinook salmon was conducted using a modified C-based version (cBAYES; Neaves et al. 2005) of the original Bayesian procedure (BAYES) outlined by Pella \& Masuda (2001). A 268-population baseline (Beacham et al. 2006a,b), comprised of 50 000 individuals ranging from Alaska to California was used to estimate mixed-stock compositions for each year and season within each catch region. In the mixedstock analysis, we assigned fish to one of 15 regional stocks and 40 sub-regional populations on the basis of genetic structure (Beacham et al. 2006b). This expanded the groupings of most regional stocks except Vancouver Island, Puget Sound, QCI, Nass River and BC Northern and Southern mainland stocks (Table S1 in the supplement at www.intres.com/articles/suppl/m449p245_supp.pdf).

In the analysis, ten 20000 -iteration Markov chain Monte Carlos were run using an uninformative prior with a value of 0.90 for a randomly picked population (Pella \& Masuda 2001). Estimated stock compositions were considered to have converged when the shrink factor was $<1.2$ for the 10 chains (Pella \& Masuda 2001) and thus the starting values were considered to be irrelevant. The posterior distributions from the last 1000 iterations for all chains were combined to estimate mean stock composition and standard error.

\section{Statistical analysis}

We tested for regional, seasonal and annual differences in CPUE through an R-based (R v2.12.2, R
Development Core Team 2011) permutation procedure (outlined below; adonis function, Vegan Community Ecology Package v1.17-8; Oksanen et al. 2011), which does not require data to be normally distributed. We applied a permutation procedure because of the problem of zero-catch for many tows (Smith 1988, Pennington 1996). We described interannual differences in regional and seasonal distribution by examining the median shifts of the catch in latitude and longitude for each season; for each year, we calculated and plotted the seasonal geographic centre of mass (Peterson et al. 2010) for the sample of Chinook salmon caught in each region. While we recognize that salmon distribution is often locally patchy, this metric is a convenient reference point weighting the regional salmon catch by both latitude and longitude. We also examined inter-annual differences in seasonal and regional body size and energy density through analysis of variance (ANOVA) on total aggregate samples of Chinook salmon. As demonstrated here and in previous work (Trudel et al. 2009, Tucker et al. 2011), regional mixed stock samples tend to be dominated by one main stock. Therefore, we were confident that there would be little stock-specific effect on pooled samples.

We employed 3 complementary multivariate techniques to explore temporal variation in regional stock compositions. First we examined large scale patterns in mixed-stock compositions by considering the 15 regional source stocks (Beacham et al. 2006a,b). Next we considered finer scale (within regional stock) distribution patterns using 40 sub-regional allocations (Beacham et al. 2006a,b). Non-metric multidimensional scaling (MDS) and ANOVA using distance matrices (adonis function, Vegan Community Ecology Package v1.17-8; Oksanen et al. 2011) were used to test for temporal and regional differences in mixed-stock composition; hierarchical agglomerative clustering based on group-averaging linkages was used to examine which mixed-stock compositions most closely resembled each other. These analyses all employed resemblance matrices constructed using pair-wise Bray-Curtis similarities $(S)$. In this application, Bray-Curtis similarity ranges from 0 (no overlap in mixed-stock composition) to 1 (identical mixed-stock composition). Bray-Curtis similarity coefficients are unaffected by changes in scale (e.g. using percent or proportions) or number of variables used, and produces a value of zero when both values being compared are zero (joint absence problem; Clarke 1993, Legendre \& Legendre 1998). Nonmetric MDS is a ranking technique based on a set of similarity coefficients, which places points in 2- or 
3-dimensional MDS space in relation to their similarity (i.e. points farther apart are less similar than those closer together). Unlike multivariate ANOVA, nonmetric MDS does not require data to be normally distributed (Clarke 1993). The non-metric MDS uses an iterative process to find the best (minimum) solution; therefore each run used 50 iterations with random starting locations. Minimum stress (a measure of agreement between the ranks of similarities and distances in 2- or 3-dimensional MDS space) was attained in multiple iterations of each run, while multiple runs of each dataset produced similar configurations, suggesting true global minimum solutions were attained with this method. ANOVA using distance matrices was employed to test for regional, seasonal and annual differences in mixed stock compositions. In so far as it partitions the sums of squares of a multivariate data set, it is directly analogous to MANOVA (McArdle \& Anderson 2001) and is a robust alternative to both parametric MANOVA and to ordination methods for describing how variation is attributed to different predictors or covariates. The function adonis can handle both continuous and factor predictors and uses permutation tests with pseudo- $F$ ratios to inspect the significances of those partitions; we used 1000 permutations. All analyses were run using R. Maps were also generated using an R-based package (PBS mapping 2.55; Schnute et al. 2008).

\section{RESULTS}

\section{Catch, distribution and biological characteristics of juvenile Chinook salmon}

Over the decade, we captured 12690 juvenile Chinook salmon from 2708 tows. CPUE varied significantly between seasons $(p<0.01)$, regions $(p<0.01)$ and years $(p<0.01)$, with significant interactions between main effects (season, region, years; all $\mathrm{p}<$ 0.02). Sample sizes and CPUE tended to be largest off the WCVI in all seasons relative to the Central Coast and SEAK (Fig. 2) and highest in the fall in all regions. The distribution of Chinook salmon in each region, as denoted by the centre of mass (Fig. 3), shifted seasonally and displayed the most interannual variation in the June-July sampling period, becoming increasingly constant by winter with salmon concentrated off the northern half of Vancou-
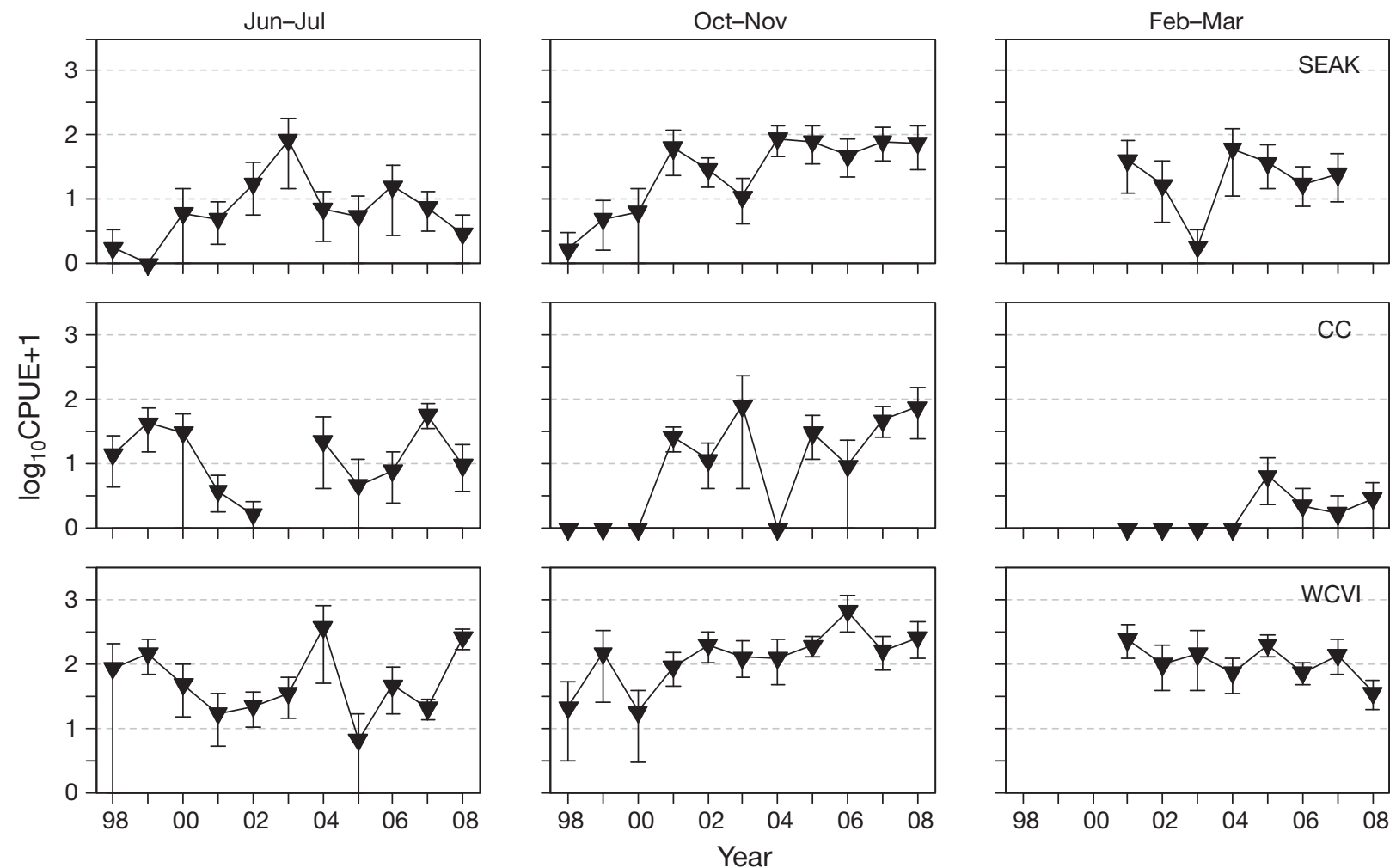

Fig. 2. Oncorhynchus tshawytscha. Interannual variation in average catch per unit effort $\left(\log _{10}[\mathrm{CPUE}+1]\right)$ for juvenile Chinook salmon by region (rows) and season (columns). Average CPUE and 95\% CI were obtained by bootstrap approximations 

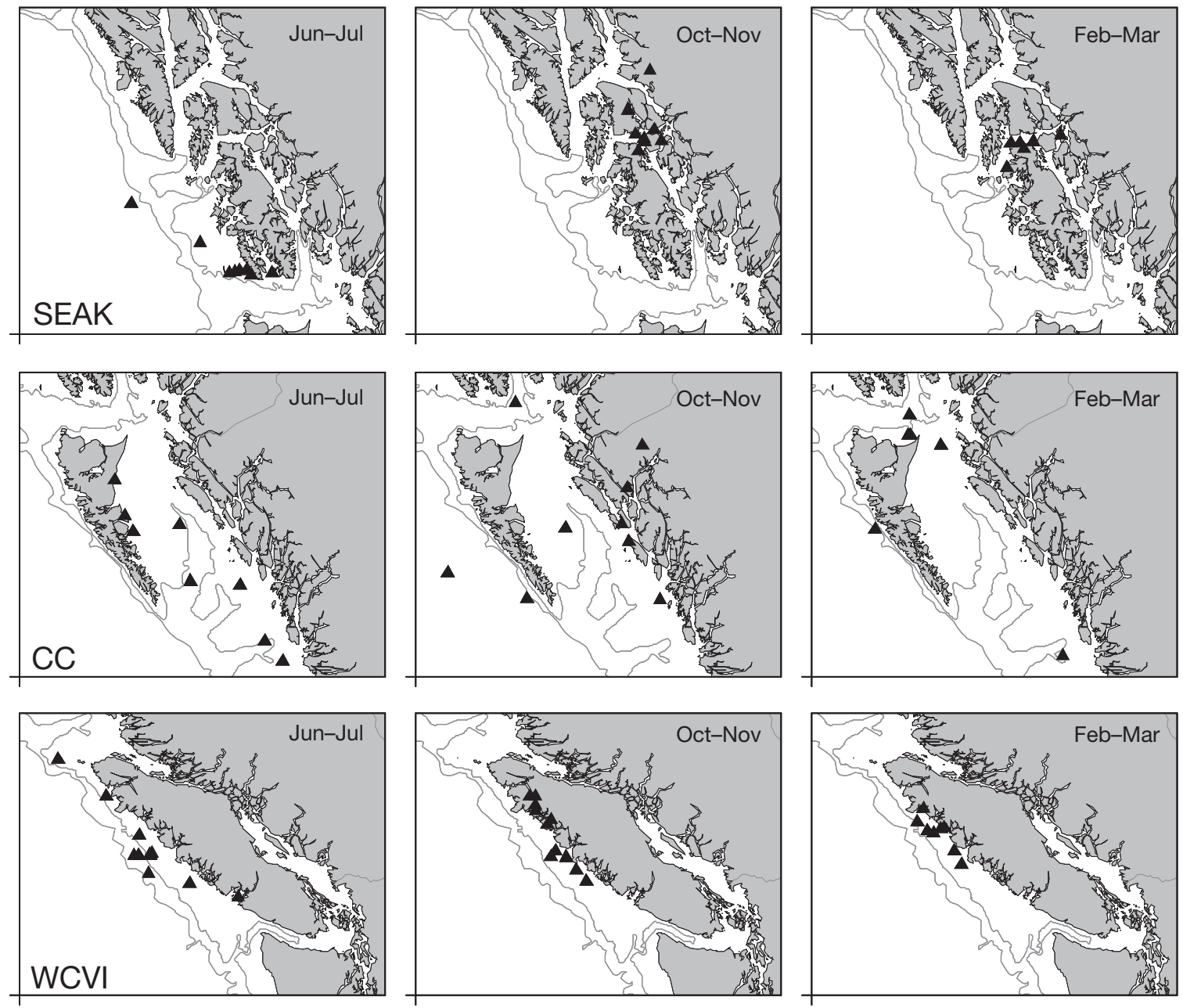

Fig. 3. Oncorhynchus tshawytscha. Centre of population mass within sampling regions. Each point represents a single year

ver Island and the inner channels of SEAK, most notably within Sumner Strait. For the most part, as a weighted indice of distribution, the centre of mass provided a reasonable representation of our catches. However, there were 2 main exceptions (SEAK in summer and $\mathrm{CC}$ in fall) where the centre of mass was well off the shelf (Fig. 3). This however is likely an artefact of the calculation.

Fish body size (length; $\mathrm{mm}$ ) varied significantly between years $(p<0.01)$, seasons $(p<0.01)$ and regions $(p<0.01)$, with significant interactions between main effects (season, region, years; all p < 0.01). Fish size was fairly uniform between regions in June to July; however, it was generally larger in SEAK and CC than WCVI within each season and year (Fig. 4). In a similar manner, fish dry wt varied significantly between years $(p<0.01)$, seasons $(p<0.01)$ and regions $(p<0.01)$ with significant interactions between main effects (all $p<0.01)$. Dry wt (a proxy for lipid concentration) was also higher in northern samples than southern samples within each season and year (Fig. 4).

\section{Trends in mixed-stock compositions}

Regional groupings

In summer, Columbia River origin Chinook salmon dominated catches in all regions in all years with increasing proportions from WCVI (average across years $84 \%$ ) to CC (89\%) and to SEAK (98\%) (Fig. 5). The WCVI stock formed the majority of the remainder of fish off WCVI (14\%), while Fraser River (4\%) and northern BC (5\%) were the next largest stocks in CC. In fall, local stocks dominated catches in all regions (e.g. $95 \%$ WCVI fish in WCVI; $87 \%$ northern $\mathrm{BC}$ and Nass and Skeena Rivers fish combined in 

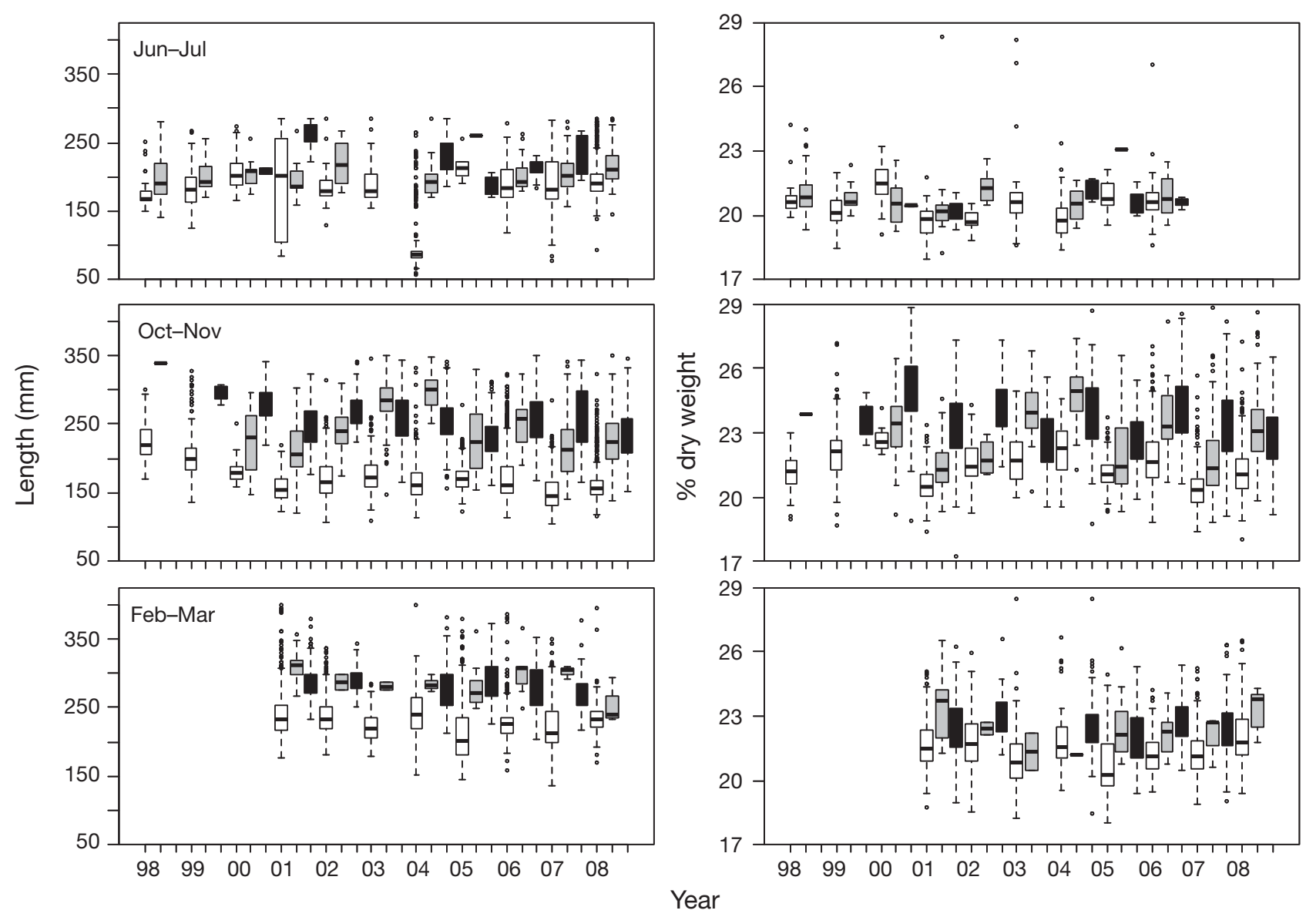

Fig. 4. Oncorhynchus tshawytscha. Box plots of seasonal fork length (mm) and dry wt (as \% of total weight) of juvenile Chinook salmon in different years. Boxes: west coast of Vancouver Island (WCVI; white) British Columbia (CC; grey), southeast Alaska (SEAK; black)

CC; $96 \%$ trans-boundary and southeast Alaska fish in SEAK). In all regions, Columbia River fish fell to $\sim 1.5 \%$ during fall, representing both a proportional and absolute decline in numerical abundance (Table 2, Fig. 5). In winter, WCVI fish continued to dominate catches in WCVI at $65 \%$ of the catch. However, there were influxes of Fraser River $(10 \%)$, Puget Sound $(11 \%)$, coastal Washington and Oregon fish $(6 \%$ combined). These represent both increases in proportion and numerical abundance (Table 2, Fig. 5) from fall when they were all present at $<1 \%$. Columbia River fish also increased to comprise $5 \%$ of the total. In CC, northern BC (43\%) and Nass and Skeena Rivers (27\%) fish were caught in the highest proportions. The remainder were primarily southeast Alaska (8\%) and WCVI (12\%) fish. Columbia River fish comprised $2 \%$ of the total. Trans-boundary and southeast Alaska (92\%) fish in SEAK continued to dominate catches. The remainder was comprised of predominantly northern BC and Nass and Skeena Rivers fish.

\section{Sub-regional groupings}

To explore whether the grouping of fish into large regional stocks influenced the impression of consistent stock composition as well as look at distribution on a finer scale, we re-examined these at the subregional level with 40 sub-populations in total. The main sub-regional stock groupings varied regionally and seasonally. All regions were dominated by Columbia River system fish in summer. Snake Riverspring/summer fish were found off WCVI to SEAK representing between 35 to $18 \%$ respectively of total Chinook salmon catches in summer. With the exception of $4 \%$ of fish in fall in SEAK, the proportion of this stock declined to $<1 \%$ in fall and winter samples. Upper Columbia River-spring Chinook salmon represented $\sim 20 \%$ of total catches in summer in all regions (Table $\mathrm{S} 1$ in the supplement). This stock constituted $4 \%$ of the catch in SEAK in fall but proportions declined to $<1 \%$ in fall and winter sampling in all other mixed stock compositions. Upper Willamette 

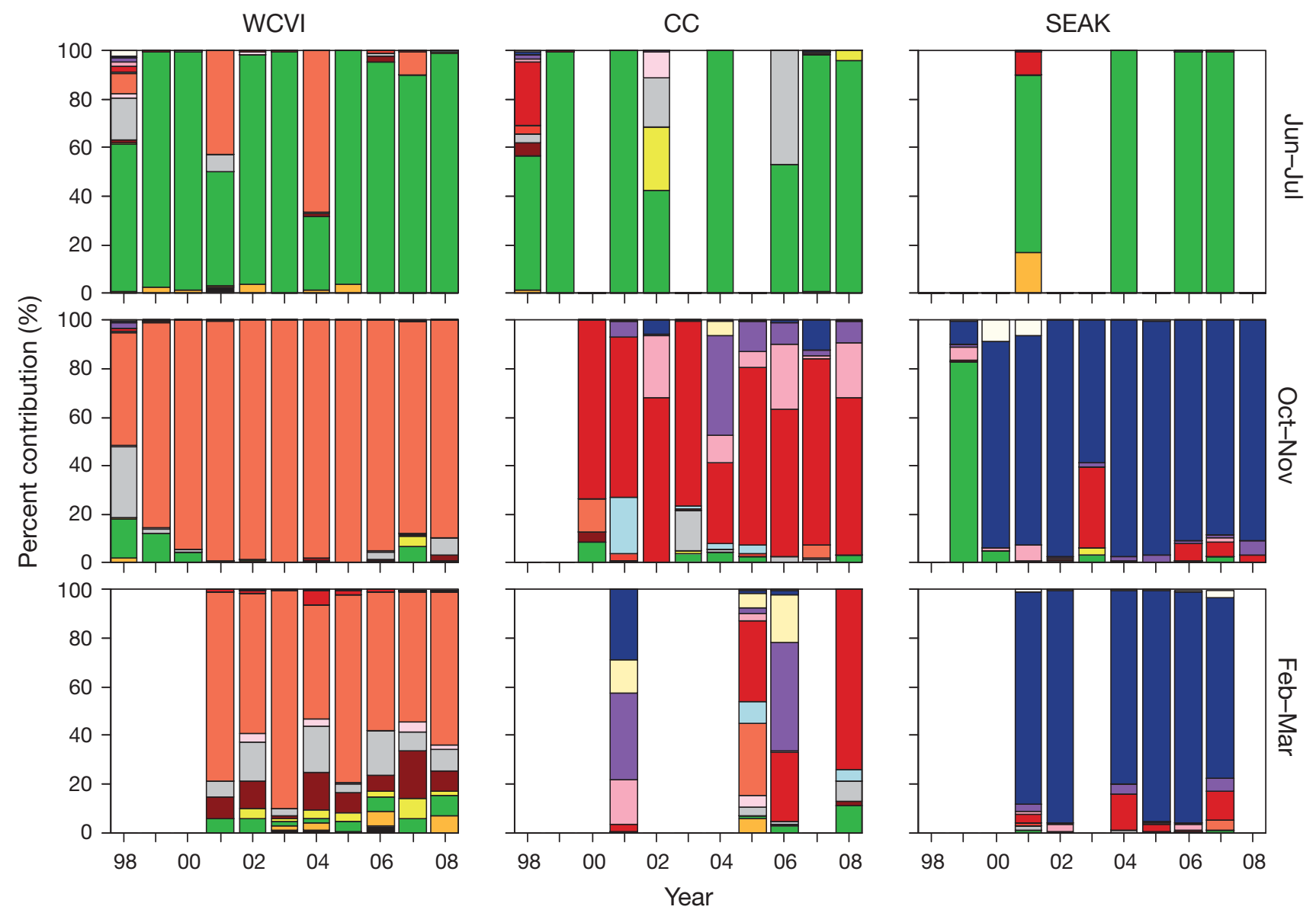

Fig. 5. Oncorhynchus tshawytscha. Estimated stock composition (\%) by region (columns) and season (rows) for 1998-2008, for 15 regional stocks. PS: Puget Sound, E/WCVI: east/west coast Vancouver Island, QCI: Queen Charlotte Islands, N/SOBC: northern/southern British Columbia, SEAK: southeast Alaska

- California

$\square$ Oregon

$\square$ Columbia R.

$\square$ Washington

$\square \mathrm{PS}$

$\square$ Fraser R.
$\square$ ECVI
$\square$ WCVI
$\square$ SOBC
$\square$ NOBC

$\square$ Nass R.

$\square$ Skeena R.

$\square \mathrm{QCl}$

Transboundary

$\square$ SEAK fish constituted $45 \%$ of fish in SEAK in summer with values of 9 and $5 \%$ in CC and WCVI respectively; they constituted $<1 \%$ in all other samples. Other subregional stocks of note (not previously defined) were the appearance of Skeena Bulkley River fish at $14 \%$ in $\mathrm{CC}$ in winter, and Unuk River at $7 \%$. In SEAK, Stikine River fish represented 57 and $78 \%$ of fish in fall and winter catches, while Taku River fish comprised 9 and $4 \%$ in fall and winter; Unuk River fish were caught at 14 and $6 \%$.

\section{Classification}

We performed hierarchical agglomerative cluster analysis to explore the classifications of the annual and seasonal mixed stock compositions. The result- ing dendrogram for regional groupings contains 4 distinct clusters (Fig. 6) with strong correspondence to catch region. Fall and winter stock compositions for the 3 major geographic regions formed distinct clusters, each of which was dominated by local stocks; that is, the 3 regions were distinct, and within each region fall and winter stock compositions were similar. The final cluster was comprised of summer catches from all regions, where stock composition was dominated by Columbia River fish. There were 3 exceptions: the 1999 SEAK fall sample grouped with the summer cluster as they were dominated by Columbia River fish, and the 2001 and 2004 WCVI summer samples grouped with the WCVI fall and winter cluster as there were large proportions of WCVI fish (43 and 66\% respectively). This analysis confirms that regional stocks dominate distribution 


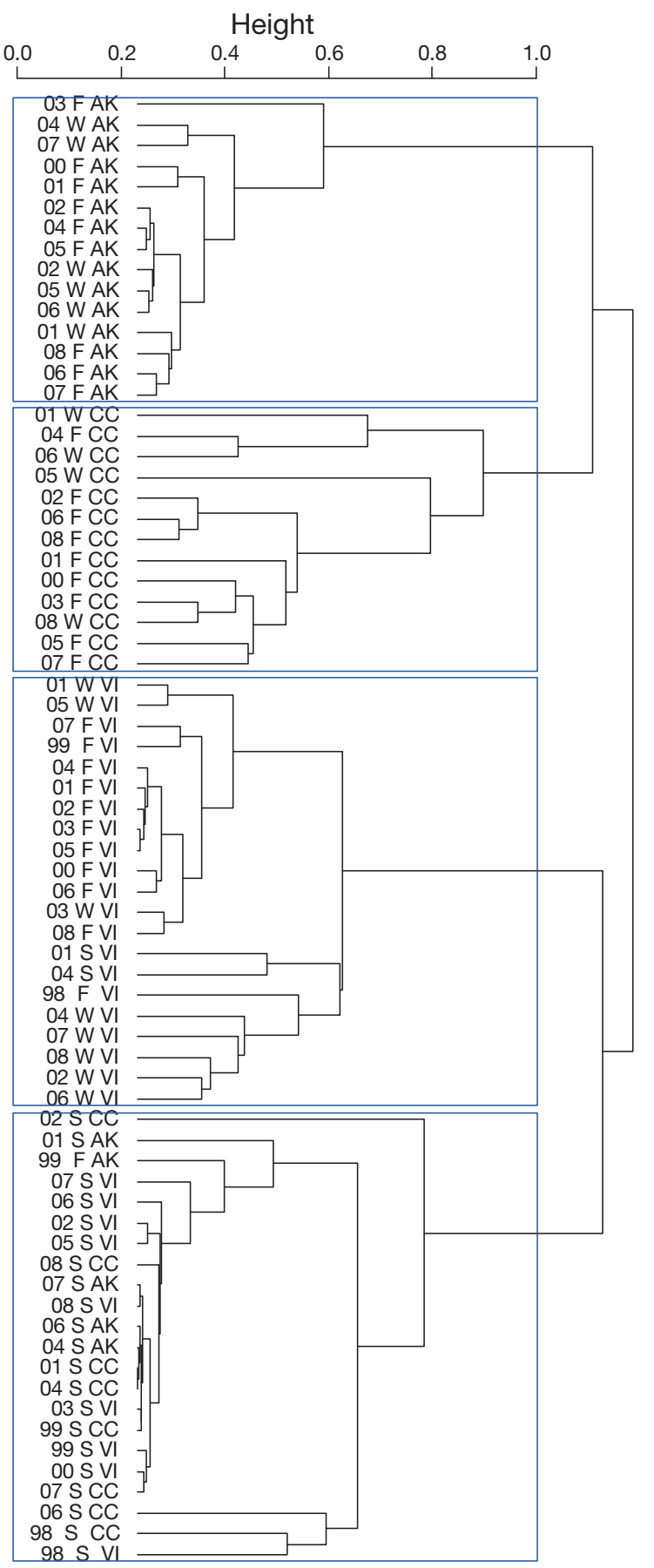

Fig. 6. Oncorhynchus tshawytscha. Hierarchical agglomerative cluster dendrogram (group-averaging linkages) of regional mixed stock compositions. Numbers = abbreviated years (e.g. 98 = 1998); $\mathrm{S}=$ summer $($ Jun-Jul), $\mathrm{F}=$ fall (Oct-Nov), W = winter (Feb-Mar); VI = west coast of Vancouver Island, $\mathrm{CC}=$ Central British Columbia, $\mathrm{AK}=$ southeast Alaska. Blue rectangles highlight main clusters

patterns with generally abrupt transitions between regions, except in summer when Columbia River Chinook salmon are migrating north.

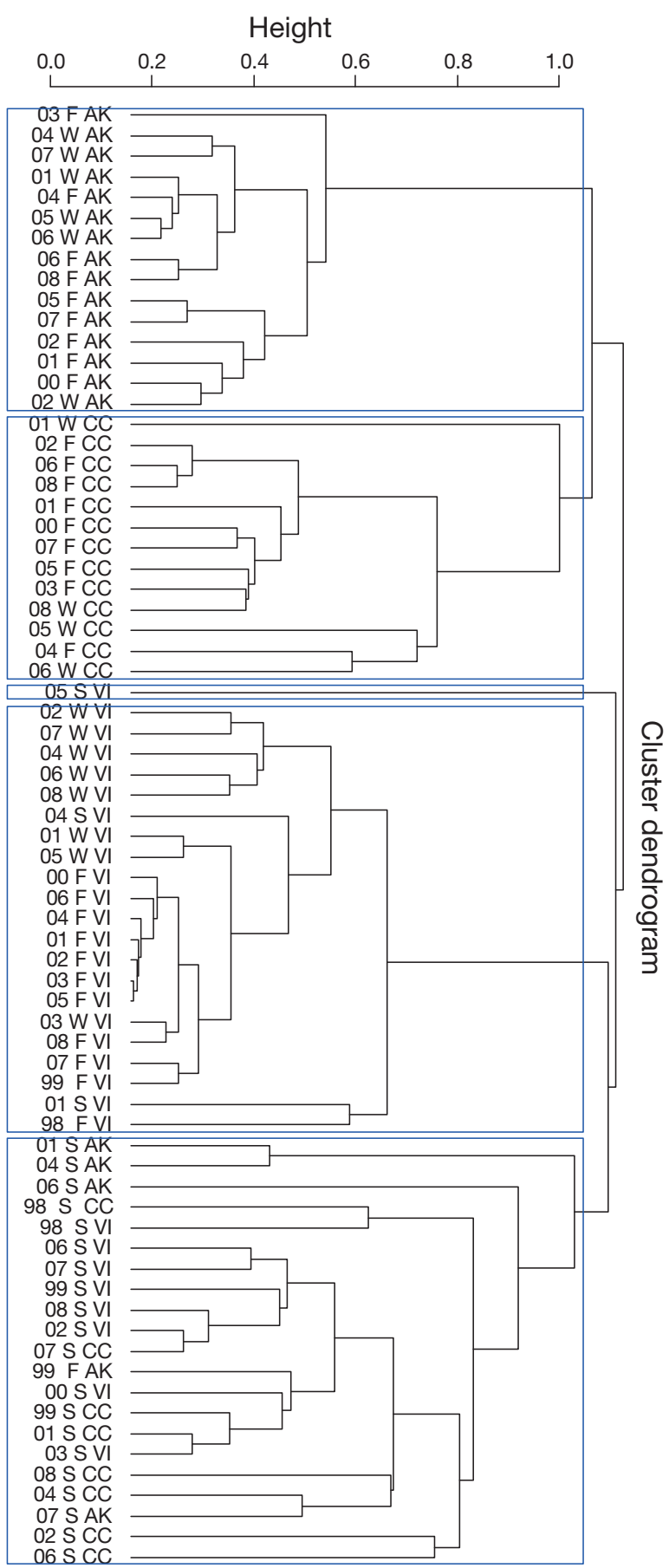

Fig. 7. Oncorhynchus tshawytscha. Hierarchical agglomerative cluster dendrogram (group-averaging linkages) of subregional mixed stock compositions. Legend as in Fig. 6

The dendrogram from the hierarchical agglomerative cluster for the sub-regional groupings contained the same 4 distinct clusters (Fig. 7) with strong correspondence to catch region. There were the same 3 exceptions as with the regional stocks. However, the 
2005 sample from summer in WCVI fell out on its own. Sample size $(n=7)$ was small and dominated by Upper Columbia River-summer/fall fish.

\section{Ordination}

Variation in mixed stock composition was explored by ordination using non-metric MDS and confirmed the patterns observed in cluster analysis as discussed above. The non-metric MDS analysis of mixed stock represented the data reasonably well (Clarke \& Warwick 2001) in 2 dimensions (2D stress $=0.14$; Fig. 8) and resulted in 4 non-overlapping groups of mixed stocks in common catch regions. This was improved in 3 dimensions (3D stress $=0.06$ ). In Fig. 8, we have also superimposed the resultant cluster configuration in the non-metric MDS plot (Clarke \& Warwick 2001, Oksanen et al. 2011); group delineation proved to be congruent between the 2 techniques. For the subregional mixed stock groupings, the $2 \mathrm{D}$ non-metric MDS stress was 0.17 , suggesting that the test performance was fair (Clarke \& Warwick 2001), also resulting in 4 distinct groups. Again, this was improved in 3 dimensions (3D stress $=0.09$ ).

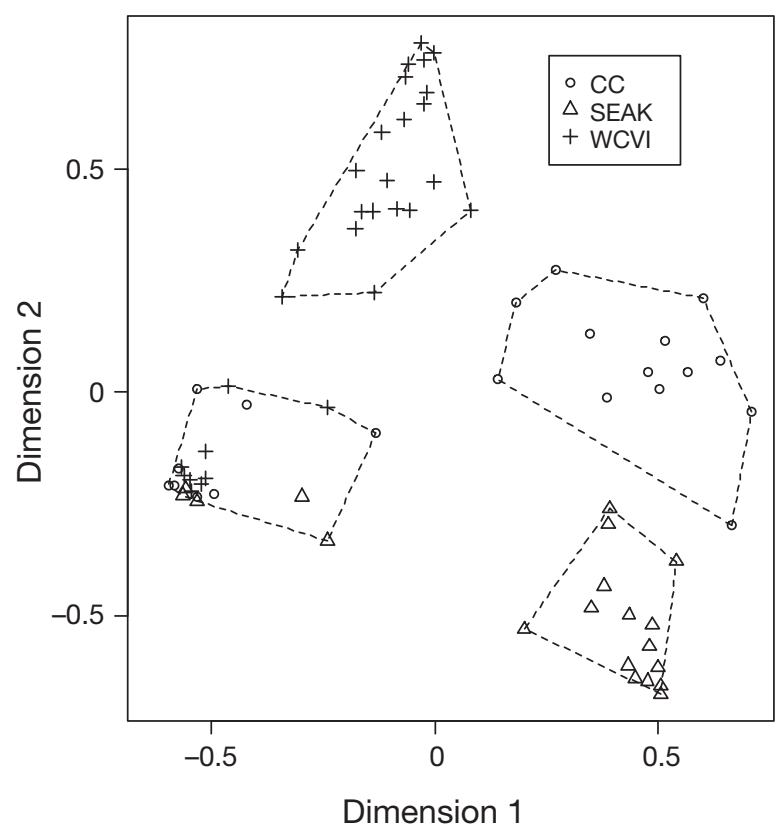

Fig. 8. Oncorhynchus tshawytscha. Non-metric multidimensional scaling ordination plot of regional mixed stock compositions (2D stress $=0.14)$. Mixed stock groupings coded by catch region. Dashed lines: resultant cluster groupings from hierarchical agglomerative cluster analysis. WCVI: west coast Vancouver Islands, CC: central British Columbia, SEAK: southeast Alaska

\section{Analysis of variance}

Examining regional mixed-stock compositions with ANOVA using the Bray-Curtis distance matrices, we found significant differences between regions $(\mathrm{p}<$ $0.01)$ and seasons $(p<0.01)$, but no effect of year $(p=$ 0.30 ). Similarly, for sub-regional groupings, we found significant differences between regions $(p<0.01)$ and seasons $(p<0.01)$, but no effect of year $(p=0.21)$.

\section{DISCUSSION}

No study to date has been able to document annual changes in stock composition and migration behaviour of juvenile salmon due to both small sample sizes (Trudel et al. 2009, Tucker et al. 2009) or the inability to identify individual stocks (e.g. Hartt \& Dell 1986). In this study, sample sizes were large enough to evaluate annual changes in migration behaviour, owing both to extensive sampling effort and the application of microsatellites for individual stock identification. There may of course be some smaller scale regional patterns in movement and distribution masked by the aggregation of fish into large sampling regions. Specific trajectories may change between years. However, the overarching patterns were consistent despite the large variations in ocean conditions encountered by salmon over the time period of our study: coastal residency of local stocks in their first year at sea except for southern yearling fish (Columbia River and coastal USA), which moved quickly into waters north of WCVI in summer.

Variable conditions in the North Pacific Ocean, as well as large overall shifts in ocean regimes and consequent shifts in primary and secondary production have been extensively documented during the period of this study (e.g. DFO 2009). In addition, previous work has outlined correlations between various environmental conditions and the presence, abundance, condition and survival of Chinook salmon (Fisher et al. 2007, Bi et al. 2007, 2011a, Wells et al. 2008, MacFarlane 2010, Peterson et al. 2010, Duffy \& Beauchamp 2011). Our objective was not to re-establish those, but to extend our understanding by evaluating the consistency in regional and seasonal stock compositions over a decade that saw large changes in ocean conditions. We demonstrate that the distribution and abundance, as well as the size and condition of fish, varied between years on a seasonal basis in all regions. No doubt these are influenced by specific environmental conditions and 
food web processes that have been previously outlined. Changes in CPUE potentially reflect changes in marine survival, although it is difficult to account for differences in freshwater recruitment and smolt production between years given the lack of information on smolt outputs for the vast majority of stocks (Pacific Salmon Commission 2009). At the very least, size and condition have important consequences for survival (Beamish \& Mahnken 2001, Moss et al. 2005, Duffy \& Beauchamp 2011, Farley et al. 2011). However, we observed no response in terms of large shifts in stock specific distributions within that first year of marine life (i.e. across all seasons). Stock composition was similar between years suggesting migration patterns for all stocks remain consistent despite large fluctuations in the marine environment. It is possible however, that under certain conditions, fish from all stocks are moving undetected beyond our sampling area in a synchronous and rapid manner that would not be reflected in our mixed stocked results. Although the scope of our sampling was large, it was not large enough to address this possibility, which has different implications for plasticity.

The similarity in regional stock compositions between years at both the regional and sub-regional stock level was demonstrated by classification and ordination procedures. Fall and winter stock compositions from each catch region formed 3 distinct clusters, each dominated by local stocks. The final cluster was comprised of summer catches from all regions, where stock composition was dominated by Columbia River yearling fish. There were 3 principal outliers to this pattern: the 1999 SEAK fall sample grouped with the summer cluster as they were dominated by Columbia River fish, and the 2001 and 2004 WCVI summer samples grouped with the WCVI fall and winter cluster as there were large proportions of WCVI fish (43 and $66 \%$ respectively). Two of these discrepancies can be explained by different sampling location and effort. In fall 1999, at the beginning of the program, we did not sample the inside passages of SEAK. This is where the vast majority $(\sim 99 \%)$ of Chinook salmon have been caught in SEAK and are overwhelmingly trans-boundary fish and other northern stocks (98\% of inside fish total). Columbia River fish tend to be caught in outside waters (5 out of 9 Chinook salmon caught in outside waters, or $55 \%$ ) and very rarely inside $(0.6 \%$ of total). Given that the 1999 fall sample size was small and as we fished only on the continental shelf rather than in the straits and inlets, this sample was likely skewed in favour of Columbia River fish. In summer, we rarely sampled the inside inlets and sounds of WCVI.
However, in 2004 and 2007, we did and subsequently caught 81 ( $\mathrm{n}=73)$ and 100\% (n = 7) WCVI fish respectively. However, in 2004 this inside catch was large and comprised $66 \%$ of the total catch; in 2007 the catch represented only $10 \%$ of the total. However, in both these cases, fishing inside waters likely skewed the catches towards WCVI fish. In 2001 we did not fish the inside waters but almost half the catch was made up of WCVI fish. Since there was no identifiable shift in location or timing of sampling, it appears this represents an early emergence of WCVI fish onto the shelf as we have never observed them here in other years. It also appeared to be a year of low abundance of Columbia River fish off WCVI but this was not a general trend across the other sampling areas, suggesting that perhaps survival conditions were very poor that year and/or fish migrated north faster.

Even at the level of sub-regional stocks, patterns remained consistent among years. In summer, Columbia River origin Chinook salmon dominated catches coast wide, representing $>90 \%$ of all Chinook salmon, suggesting a rapid northward migration for many fish. The vast majority of these were spring-run Chinook salmon that moved quickly into waters north of Vancouver Island, including southeast Alaska. The primary stocks were Snake Riverspring/summer, Upper Columbia River-spring and Upper Willamette. These tend to be yearling smolts suggesting a component of life history variation in migration pattern (Trudel et al. 2009, Tucker et al. 2011). However, there were some Chinook salmon from Upper Columbia summer-fall runs that were found off WCVI in significant proportions, though none were identified north of Vancouver Island. In contrast, these tend to be sub-yearling smolts. However, the vast majority of sub-yearling smolts from other Columbia River stocks are first caught in these waters in fall (Tucker et al. 2011). This would suggest that, with respect to migration patterns, at least for Upper Columbia River fish, there may be some affinity to the river of origin and ESU (Waples et al. 2004)

Columbia River fish subsequently became minor components in catches in fall and winter as proportions declined to $<20 \%$ of Chinook salmon caught. The majority of these fish were fall-run, sub-yearling Chinook salmon primarily from the Upper Columbia River. In general, fall-run and spring-run Chinook display opposing migration patterns with either a period of coastal residency or rapid migration respectively (Trudel et al. 2009, Tucker et al. 2011, J. Fisher unpubl.). Given the propensity of juvenile Chinook salmon for local residency in the first year of marine 
life (current study, Murphy et al. 2009, Trudel et al. 2009, Tucker et al. 2011), some sub-regional populations were likely over or under-represented in the broad regional mixed-stock analysis particularly at the edges of our sampling area. For example in SEAK, our sample is weighted by Stikine River fish, even though escapements are on the same order as the Taku River (Pacific Salmon Commission 2009). Similarly, based on the small escapements of Unuk River fish, these are likely over-represented in our sample (Pacific Salmon Commission 2009). This is likely due to concentration of our fishing effort in the southern portion of SEAK in closer proximity to the Stikine and Unuk Rivers.

Little inter-annual stock-specific change in marine distributions, despite changes in ocean conditions, would suggest that Chinook salmon distributions are primarily driven by genetic control of migration (Brannon \& Setter 1989, Kallio-Nyberg \& Ikonen 1992) than by either local environmental conditions (Hodgson et al. 2006) or opportunistic foraging opportunities (Healey 2000). Conversely, the differences in ocean conditions observed during this time span were not large enough to effect a measurable change in stock specific distributions in spite of the fact that growth, condition (present study), and survival (Pacific Salmon Commission 2009) all varied substantially over this decade. This seems unlikely however given that what would generally be considered 'extreme' climatic events were observed over this timeframe. For example, a major El Niño warming event in 1998 was followed by near normal conditions in 1999 with moderate La Niña conditions in 2000. These moderate La Niña conditions persisted in 2001 in the northeast Pacific and coastal British Columbia. However, in 2002 weak El Niño conditions occurred in the second half of the year. The weak El Niño of 2002 to 2003 set up anomalously warm sea surface temperatures to mid 2003 when the ocean surface waters cooled somewhat, returning to more average temperatures until early 2004. In May 2004, the coastal ocean waters off British Columbia were above average in temperature; these were maintained into 2006 in the entire northeast Pacific (Mackas et al. 2006). However, except for a brief warm period in summer, ocean waters were cooler than normal through 2007 and into 2008. These cooler temperatures were associated with La Niña conditions in spring and autumn 2007. Despite continuing increases in overall global water temperatures, the waters off the Pacific coast of Canada in 2008 were the coldest in $50 \mathrm{yr}$, and the cooling extended far into the Pacific Ocean and south along the American coast. Shifts in zooplankton abundances and species assemblages were coincident with the large scale changes in ocean temperature (DFO 2009). In 1998, indeed during the previous decade, zooplankton assemblages in the NE Pacific were dominated by 'southerly' copepod fauna (DFO 2000). In 1999, following the strong La Niña that began in late 1998 in the equatorial Pacific, the concentrations of all of the major zooplankton taxa swung sharply back toward or past their long term average levels to more boreal and sub-arctic assemblages into 2002. Zooplankton communities again returned to 'cool-ocean' species in 2007; this trend continued into 2008. This is in contrast to the previous 3 yr during which warm water, southern species predominated.

There is, of course, a further question as to whether widespread and stable marine distributions may exist in other Pacific salmon and other fish species, and may be a universal evolutionary response to dynamic marine environments. Chinook salmon appear to be unique in their migration strategy of coastal residence as many fish do not appear to leave the shelf until after their second summer at sea (Murphy et al. 2009, Trudel et al. 2009, Tucker et al. 2011). In contrast, juvenile sockeye Oncorhynchus nerka, coho, pink O. gorbucha and chum salmon O. keta are thought to leave coastal shelf waters between fall and the onset of spring (Fisher et al. 2007, Morris et al. 2007, Tucker et al. 2009) or possibly earlier (M. Trudel unpubl. data). Given the rapid movement of juvenile sockeye and coho salmon (species for which we have stock-specific data), compared to the resident pattern of sub-yearling Chinook salmon, it is unlikely that mixed-stock compositions per se would remain constant as in the case here. However, by examining the composite distribution of individuals from particular stocks separately, it is clear that stocks consistently display similar migration patterns from year to year (S. Tucker unpubl. data). For example, over a 10 yr period, Fraser River sockeye salmon stocks left the Strait of Georgia in spring/early summer via a northern route though Johnstone Strait into Queen Charlotte Sound. The exception was Harrison River fish, which migrated via the southern route through Juan de Fuca continuing north off the West Coast of Vancouver at some point in the winter (Tucker et al. 2009, S. Tucker unpubl. data). So while the specific timing of migration might vary between years, and there may be very local effects on survival for specific stocks resulting in different regional mixed-stock compositions, the patterns displayed are consistent from one year to the next. 
Few studies have been successful in linking the effects of ocean conditions on Chinook salmon production (e.g. Beamish et al. 1995, Ruggerone \& Goetz 2004, Scheuerell \& Williams 2005, Wells et al. 2006, $2007,2008)$. The results of such analyses are often difficult to interpret since they rely on large-scale climate indices that may not always reflect the very specific areas where individual stocks of Chinook salmon seem to be resident. The results outlined here and in Trudel et al. (2009) underline the importance of considering relevant spatial and temporal scales for assessing the effects of ocean conditions on Pacific salmon, particularly since there is increasing evidence that recruitment is potentially set within the first year of marine life (Pearcy 1992, Beamish \& Mahnken 2001, Beamish et al. 2004, Cross et al. 2009, Duffy \& Beauchamp 2011). Our analyses indicate that relevant spatial and temporal scales vary with stock and life history. Effects of ocean conditions on fall Chinook salmon are expected to be manifested at a local scale for coastal stocks (i.e. within 200 to $400 \mathrm{~km}$ of the natal river), compared to the scale of the northern California Current (i.e. California/Oregon to the west coast of Vancouver Island) for southern US origin fall fish. Even broader and more complex spatial and temporal scales must be considered for southern US spring Chinook salmon, as ocean conditions vary among both regions and months, and stocks are distributed across the shelf. The limited inter-annual variation in marine distributions evident for both juvenile Chinook salmon in the present study and adult Chinook salmon (Weitkamp 2010), despite highly variable ocean conditions, suggests that poor ocean conditions may result in poor survival rather than adaptive alterations in movement and distribution. If this is true, various scenarios of climate change and accompanying increases in ocean temperatures with unfavourable growing conditions do not bode well particularly for southern stocks of Chinook salmon. These essentially predict that these stocks will increasingly be more likely to encounter areas of low growth and survival (however see Sydeman et al. 2011). If so, then the marine survival and resulting conservation status of individual salmon stocks may be strongly determined by their entry point into the ocean, which discrete oceanographic regions they encounter, and their duration of residency within each region.

Acknowledgements. We thank the crews of the CCGS 'W.E. Ricker', FV 'Ocean Selector', FV 'Frosti' and FV 'Viking Storm' and the numerous scientists and technicians for their assistance with the field work and laboratory analysis, the Bonneville Power Administration and Fisheries and Oceans Canada for their financial support.

\section{LITERATURE CITED}

Båmstedt U (1986) Chemical composition and energy content. In: Corner EDS, O'Hara SCM (eds) The biological chemistry of marine copepods. Clarendon, Oxford, p 1-58

Batten SD, Freeland HJ (2007) Plankton populations at the bifurcation of the North Pacific Current. Fish Oceanogr 16:536-646

> Batten S, Hyrenbach D, Sydeman W, Morgan K, Henry M, Yen P, Welch DW (2006) Characterising meso-marine ecosystems of the North Pacific. Deep-Sea Res II 53: 270-290

Beacham TD, Candy JR, Jonsen KL, Supernault J and others (2006a) Estimation of stock composition and individual identification of Chinook salmon across the Pacific Rim by use of microsatellite variation. Trans Am Fish Soc 135: 861-888

Beacham TD, Jonsen KL, Supernault J, Wetklo M, Deng L, Varnavskaya N (2006b) Pacific Rim population structure of Chinook salmon as determined from microsatellite analysis. Trans Am Fish Soc 135:1604-1621

> Beamish RJ, Mahnken C (2001) A critical size and period hypothesis to explain natural regulation of salmon abundance and the linkage to climate and climate change. Prog Oceanogr 49:423-437

Beamish RJ, Riddell BE, Neville CM, Thomson BL, Zhang Z (1995) Declines in Chinook salmon catches in the Strait of Georgia in relation to shifts in the marine environment. Fish Oceanogr 4:243-256

Beamish RJ, McFarlane GA, Schweigert J (2001) Is the production of coho salmon in the Strait of Georgia linked to the production of Pacific Herring? In: Funk F, Blackburn J, Hay D, Paul AJ, Stephenson R, Toresen R, Witherell D (eds) Herring: expectations for a new millenium. University of Alaska Sea Grant, AK-SG-01-04, Fairbanks, AK, p 37-50

Beamish RJ, Sweeting RM, Neville CE, Poier K (2002) A climate related explanation for the natural control of Pacific salmon abundance in the first marine year. NPAFC Technical Report No. 4

- Beamish RJ, Mahnken C, Neville CM (2004) Evidence that reduced early marine growth is associated with lower marine survival of coho salmon. Trans Am Fish Soc 133: 26-33

Bi H, Ruppel R, Peterson WT (2007) Modeling the pelagic habitat of salmon off the Pacific Northwest (USA) coast using logistic regression. Mar Ecol Prog Ser 336:249-265

Bi H, Ruppel RE, Peterson WT, Casillas E (2008) Spatial distribution of ocean habitat of yearling Chinook (Oncorhynchus tshawytscha) and coho (Oncorhynchus kisutch) salmon off Washington and Oregon, USA. Fish Oceanogr 17:463-476

Bi H, Peterson WT, Lamb J, Casillas E (2011a) Copepods and salmon: characterizing the spatial distribution of juvenile salmon along the Washington and Oregon coast, USA. Fish Oceanogr 20:125-138

Bi H, Peterson WT, Strub T (2011b) Transport and coastal zooplankton communities in the northern California Current system. Geophys Res Lett 38:L12607. doi:10.1029/ 2011GL047927

Brannon E, Setter A (1989) Marine distribution of a hatchery fall Chinook salmon population. In: Brannon EL, Jonsson B (eds) Proc Salmonid Migration and Distribution Symp. University of Washington, Seattle, WA, p 63-69 
Brodeur RD, Boehlert GW, Casillas E, Eldridge MB and others (2000) A coordinated research plan for estuarine and ocean research on Pacific salmon. Fisheries (Bethesda, Md) 25:7-16

Brodeur RD, Fisher JP, Teel DJ, Emmett RL, Casillas E, Miller TW (2004) Juvenile salmonid distribution, growth, condition, origin, and environmental and species associations in the Northern California Current. Fish Bull 102: 25-46

> Clarke KR (1993) Non-parametric multivariate analyses of changes in community structure. Aust J Ecol 18: $117-143$

Clarke KR, Warwick RM (2001) Changes in marine communities: an approach to statistical analysis and interpretation, 2nd edn. PRIMER-E, Plymouth Marine Laboratory, Plymouth

Cross AD, Beauchamp DA, Moss JH, Myers KW (2009) Interannual variability in early marine growth, sizeselective mortality, and marine survival for Prince William Sound pink salmon. Mar Coast Fish: Dyn Manage Ecosyst Sci 1:57-70

DFO (2000) 1999 Pacific region state of the ocean. DFO Can Sci Advis Sec Sci Advis Rep 2000/01

DFO (2009) State of the Pacific Ocean 2008. DFO Can Sci Advis Sec Sci Advis Rep 2009/030

> Duffy EJ, Beauchamp DA (2011) Rapid growth in the early marine period improves the marine survival of Chinook salmon (Oncorhynchus tshawytscha) in Puget Sound, Washington. Can J Fish Aquat Sci 68:232-240

Farley EV, Starovoytov A, Naydenko S, Heintz R and others (2011) Implications of a warming eastern Bering Sea for Bristol Bay sockeye salmon. ICES J Mar Sci 68: 1138-1146

Fisher J, Trudel M, Ammann A, Orsi JA and others (2007) Comparison of the coastal distributions and abundances of juvenile Pacific salmon from Central California to the Northern Gulf of Alaska. In: Grimes CB, Brodeur RD, Haldorson LJ, McKinnell SM (eds) The ecology of juvenile salmon in northeast Pacific Ocean: regional comparisons. Am Fish Soc Symp 57, Bethesda, MD, p 31-80

Fritz H, Said S, Weimerskirch H (2003) Scale-dependent hierarchical adjustments of movement patterns in a longrange foraging seabird. Proc Biol Sci 270:1143-1148

Gargett AE (1997) The optimal stability 'window': a mechanism underlying decadal fluctuations in North Pacific salmon stocks? Fish Oceanogr 6:109-117

Hare SR, Mantua NJ, Francis RC (1999) Inverse production regimes: Alaskan and West Coast Pacific salmon. Fisheries 24:6-14

Hartt AC, Dell MB (1986) Early oceanic migrations and growth of juvenile Pacific salmon and steelhead trout. Bull Int North Pac Fish Comm 46:1-105

Healey MC (1991) Life history of Chinook salmon (Oncorhynchus tshawytscha). In: Groot C, Margolis L (eds) Pacific salmon life histories. University of British Columbia Press, Vancouver, p 311-394

Healey MC (2000) Pacific salmon migrations in a dynamic ocean. In: Harrison PJ, Parsons TR (eds) Fisheries oceanography: an integrative approach to fisheries ecology and management. Blackwell Science, Oxford, p 29-54

Hickey BM, Banas NM (2008) Why is the northern end of the California Current System so productive? Oceanography 21:90-107
Hodgson S, Quinn TP, Hilborn R, Francis RC, Rogers DE (2006) Marine and freshwater climatic factors affecting interannual variation in the timing of return migration to fresh water of sockeye salmon (Oncorhynchus nerka). Fish Oceanogr 15:1-24

Hollowed A, Wooster WS (1992) Variability of winter ocean conditions and strong year classes of northeast Pacific groundfish. ICES Mar Sci Symp 195:433-444

$>$ Hurst TP (2007) Causes and consequences of winter mortality in fishes. J Fish Biol 71:315-345

Kallio-Nyberg I, Ikonen E (1992) Migration pattern of two salmon stocks in the Baltic Sea. ICES J Mar Sci 49: 191-198

Legendre P, Legendre L (1998) Numerical ecology, 2nd English edn. Elsevier Press, New York, NY

MacFarlane RB (2010) Energy dynamics and growth of Chinook salmon (Oncorhynchus tshawytscha) from the Central Valley of California during the estuarine phase and first ocean year. Can J Fish Aquat Sci 67:1549-1565

> Mackas DL, Peterson WT, Zamon JE (2004) Comparisons of interannual biomass anomalies of zooplankton communities along the continental margins of British Columbia and Oregon. Deep-Sea Res II 51:875-896

Mackas DL, Peterson WT, Ohman MD, Lavaniegos BE (2006) Zooplankton anomalies in the California Current system before and during the warm ocean conditions of 2005. Geophys Res Lett 33:L22S07. doi:10.1029/2006GL 027930

Mackas DL, Batten S, Trudel M (2007) Time series of the Northeast Pacific effects on zooplankton of a warmer ocean: recent evidence from the Northeast Pacific. Prog Oceanogr 75:223-252

- Mantua NJ, Hare SR, Zhang Y, Wallace JM, Francis RC (1997) A Pacific decadal climate oscillation with impacts on salmon. Bull Am Meteorol Soc 78:1069-1079

McArdle BH, Anderson MJ (2001) Fitting multivariate models to community data: a comment on distance-based redundancy analysis. Ecology 82:290-297

Morris JFT, Trudel M, Thiess ME, Sweeting RM and others (2007) Stock-specific migrations of juvenile coho salmon derived from coded-wire tag recoveries on the continental shelf of Western North America. In: Grimes CB, Brodeur RD, Haldorson LJ, McKinnell SM (eds) The ecology of juvenile salmon in northeast Pacific Ocean: regional comparisons. Am Fish Soc Symp 57, Bathesda, MD, p 81-104

> Moss JH, Beauchamp DA, Cross AD, Myers KW, Farley EV Jr, Murphy JM, Helle JH (2005) Evidence for sizeselective mortality after the first summer of ocean growth by pink salmon. Trans Am Fish Soc 134:1313-1322

Mueter FJ, Ware DM, Peterman RM (2002) Spatial correlation patterns in coastal environmental variables and survival rates of salmon in the north-east Pacific Ocean. Fish Oceanogr 11:205-218

Murphy JM, Templin WD, Farley Jr, EV, Seeb JE (2009) Stock-structured distribution of western Alaska and Yukon juvenile Chinook salmon (Oncorhynchus tshawytscha) from United States BASIS surveys, 2002-2007. North Pac Anadromous Fish Comm Bull 5:51-59

Neaves PI, Wallace CG, Candy JR, Beacham TD (2005) CBayes: computer program for mixed stock analysis of allelic data. Version 4.01, available at www.pac.dfo-mpo. gc.ca/sci/mgl/Cbayes_e.htm

Oksanen J, Blanchet FG, Kindt R, Legendre P and others (2011). vegan: Community Ecology Package. R package 
version 1.17-8, available at http://CRAN.R-project.org/ package $=$ vegan

Orsi JA, Jaenicke HW (1996) Marine distribution and origin of prerecruit Chinook salmon, Oncorhynchus tshawytscha, in Southeastern Alaska. Fish Bull 94:482-497

Orsi JA, Harding JA, Pool SS, Brodeur RD and others (2007) Epipelagic fish assemblages associated with juvenile Pacific salmon in neritic waters of the California Current and the Alaska Current. In: Grimes CB, Brodeur RD, Haldorson LJ, McKinnell SM (eds) The ecology of juvenile salmon in northeast Pacific Ocean: regional comparisons. Am Fish Soc Symp 57, Bethesda MD, p 105-156

Pacific Salmon Commission (2009) Annual report of catches and escapements. Joint Chinook Tech Comm Rep TCCHINOOK (09)-1

Pearcy WG (1992) Ocean ecology of North Pacific salmonids. University of Washington Press, Seattle, WA

Pella J, Masuda M (2001) Bayesian methods for analysis of stock mixtures from genetic characters. Fish Bull 99: 151-167

Pennington M (1996) Estimating the mean and variance of highly skewed marine data. Fish Bull 94:498-505

Peterson W (2009) Copepod species richness as an indicator of long term changes in the coastal ecosystem of the northern California Current. CCOFI Rep 50:73-81

> Peterson WT, Morgan CA, Fisher JP, Casillas E (2010) Ocean distribution and habitat associations of yearling coho (Oncorhynchus kisutch) and Chinook (O. tshawytscha) salmon in the northern California Current. Fish Oceanogr 19:508-525

Quinn TP, Dickerson BR, Vøllestada LA (2005) Marine survival and distribution patterns of two Puget Sound hatchery populations of coho (Oncorhynchus kisutch) and Chinook (Oncorhynchus tshawytscha) salmon. Fish Res 76: 209-220

R Development Core Team (2011) R: a language and environment for statistical computing. R Foundation for Statistical Computing, Vienna, available at www.r-project. org

Rechisky ER, Welch DW, Porter AD, Jacobs MC, Ladouceur A (2009) Experimental measurement of hydrosysteminduced mortality in juvenile Snake River spring Chinook salmon using a large-scale acoustic array. Can J Fish Aquat Sci 66:1019-1024

Ruggerone GT, Goetz FA (2004) Survival of Puget Sound Chinook salmon (Oncorhynchus tshawytscha) in response to climate-induced competition with pink salmon (Oncorhynchus gorbuscha). Can J Fish Aquat Sci 61: 1756-1770

Satterfield FR, Finney BP (2002) Stable isotope analysis of Pacific salmon: insight into trophic status and oceanographic conditions over the last 30 years. Prog Oceanogr 53:231-246

Scheuerell MD, Williams JG (2005) Forecasting climateinduced changes in the survival of Snake River spring/ summer Chinook salmon (Oncorhynchus tshawytscha). Fish Oceanogr 14:448-457

Schnute JT, Boers NM, Haigh R, Couture-Beil A (2008) PBS mapping 2.55: user's guide revised. Can Tech Rep Fish Aquat Sci 2549:1-118

Smith SJ (1988) Evaluating the efficiency of the deltadistribution mean estimator. Biometrics 44:485-493

Strub PT, James C (2002) Altimeter-derived surface circulation in the large-scale NE Pacific Gyres. Part 1: seasonal variability. Prog Oceanogr 53:163-183
Sydeman WJ, Thompson SA, Field JC, Peterson WT and others (2011) Does positioning of the North Pacific Current affect downstream ecosystem productivity? Geophys Res Lett 38:L12606. doi:10.1029/2011GL047212

> Teel DJ, Milner GB, Winans GA, Grant WS (2000) Genetic population structure and origin of life history types in Chinook salmon in British Columbia, Canada. Trans Am Fish Soc 129:194-209

> Trudel M, Tucker S, Morris JFT, Higgs DA, Welch DW (2005) Indicators of energetic status in juvenile coho salmon and Chinook salmon. N Am J Fish Manage 25: 374-390

Trudel M, Thiess ME, Bucher C, Farley EV Jr and others (2007) Regional variation in the marine growth and energy accumulation of juvenile Chinook salmon and coho salmon along the west coast of North America. In: Grimes CB, Brodeur RD, Haldorson LJ, McKinnell SM (eds) The ecology of juvenile salmon in northeast Pacific Ocean: regional comparisons. Am Fish Soc Symp 57, Bethesda, MD, p 205-232

Trudel M, Fisher J, Orsi JA, Morris JFT and others (2009) Distribution and migration of juvenile Chinook salmon derived from coded-wire tag recoveries along the continental shelf of western North America. Trans Am Fish Soc 138:1369-1391

Tucker S, Trudel M, Welch DW, Candy JR and others (2009) Seasonal stock-specific migration of juvenile sockeye salmon along the west coast of North America; implications for growth. Trans Am Fish Soc 138:1458-1480

Tucker S, Trudel M, Welch DW, Morris JFT, Candy JR, Wallace C, Beacham TD (2011) Life-history and seasonal stock-specific ocean migration of juvenile Chinook salmon. Trans Am Fish Soc 140:1101-1119

Turchin P (1998) Quantitative analysis of movement: measuring and modeling population redistribution in plants and animals. Sinauer Associates, Sunderland, MA

Waples RS, Teel DJ, Myers JM, Marshall AR (2004) Lifehistory divergence in Chinook salmon: historic contingency and parallel evolution. Evolution 58:386-403

Ware DM, McFarlane GA (1989) Fisheries production domains in the Northeast Pacific Ocean. Can Spec Publ Fish Aquat Sci 108:359-379

- Ware DM, Thomson RE (2005) Bottom-up ecosystem trophic dynamics determine fish production in the northeast Pacific. Science 308:1280-1284

> Weitkamp L (2010) Marine distributions of Chinook salmon from the West Coast of North America determined by coded wire tag recoveries. Trans Am Fish Soc 139: $147-170$

> Weitkamp L, Neely K (2002) Coho salmon (Oncorhynchus kisutch) ocean migration patterns: insight from marine coded-wire tag recoveries. Can J Fish Aquat Sci 59: 1100-1115

Welch DW, Parsons TR (1993) $\delta^{13} \mathrm{C}-\delta^{15} \mathrm{~N}$ values as indicators of trophic position and competitive overlap for Pacific salmon (Oncorhynchus spp.). Fish Oceanogr 2:11-23

Welch DW, Melnychuk MC, Rechisky EL, Porter AD and others (2009) Freshwater and marine migration and survival of endangered Cultus Lake sockeye salmon smolts using POST, a large-scale acoustic telemetry array. Can J Fish Aquat Sci 66:736-750

Welch DW, Melnychuk MC, Payne J, Rechisky EL and others (2011) In situ measurement of coastal ocean movements and survival of juvenile Pacific salmon. Proc Natl Acad Sci USA 108:8708-8713 
Wells BK, Grimes CB, Field JC, Reiss CS (2006) Covariation between the average lengths of mature coho (Oncorhynchus kisutch) and Chinook salmon (Oncorhynchus tshawytscha) and the ocean environment. Fish Oceanogr 15:67-79

Wells B, Grimmes CB, Waldvogel J (2007) Quantifying the effects of wind, upwelling, curl, sea surface temperature and sea level height on growth and maturation of a California Chinook salmon (Oncorhynchus tshawytscha) population. Fish Oceanogr 16:363-382

Wells BK, Grimes CB, Sneva JG, McPherson S, Waldvogel JB (2008) Relationships between oceanic conditions and growth of Chinook salmon (Oncorhynchus tshawytscha) from California, Washington, and Alaska, USA. Fish Oceanogr 17:101-125

Editorial responsibility: Nicholas Tolimieri, Seattle, Washington, USA
Willette TM, Cooney RT, Patrick V, Mason DM, Thomas GL, Scheel TD (2001) Ecological processes influencing mortality of juvenile pink salmon (Oncorhynchus gorbuscha) in Prince William Sound, Alaska. Fish Oceanogr 10(Suppl 1):14-41

Withler RE, Le KD, Nelson RJ, Miller KM, Beacham TD (2000) Intact genetic structure and high levels of genetic diversity in bottlenecked sockeye salmon (Oncorhynchus nerka) populations of the Fraser River, British Columbia, Canada. Can J Fish Aquat Sci 57: 1985-1998

Zamon JE, Welch DW (2005) Rapid shift in zooplankton community composition on the northeast Pacific shelf during the 1998-1999 El Niño-La Niña event. Can J Fish Aquat Sci 62:133-144

Submitted: August 11, 2011; Accepted: November 23, 2011 Proofs received from author(s): February 23, 2012 